\title{
Government-Subsidized Restaurants as promoters of the realization of the Human Right to Adequate Food: Proposal of an evaluation model
}

\section{Restaurantes Populares enquanto promotores \\ da realização do Direito Humano à}

\author{
Alimentação Adequada: proposição de \\ um modelo avaliativo
}

\author{
Juliana Theodora Cunha de OLIVEIRA ${ }^{1}$ iD 0000-0003-4671-372X \\ Cristine Garcia GABRIEL ${ }^{1}$ (ID) 0000-0002-5413-0826 \\ Mick Lennon MACHADO ${ }^{1}$ (D)0000-0001-7550-1692 \\ Marinez Fregulia RÉOS² (D) 0000-0002-2280-9420 \\ Claudia SOAR ${ }^{2}$ iD 0000-0002-7079-2360 \\ Débora Kurrle Rieger VENSKE ${ }^{1}$ iD 0000-0002-8726-8899
}

A B S T R A C T

\section{Objective}

This article presents an evaluation model for Government-Subsidized Restaurants within the framework of the National Food and Nutrition Security Policy.

\footnotetext{
1 Universidade Federal de Santa Catarina, Centro de Ciências da Saúde, Programa de Pós-Graduação em Nutrição. Campus Universitário Reitor João David Ferreira Lima, s/n., Trindade, 88040-900, Florianópolis, SC, Brasil. Correspondence to: CG GABRIEL. E-mail: <cristine.gabriel@ufsc.br>.

2 Universidade Federal de Santa Catarina, Centro de Ciências da Saúde, Departamento de Nutrição. Florianópolis, SC, Brasil.

Support: This research was funded by the Secretaria Nacional de Segurança Alimentar e Nutricional (Food and Nutrition Security Department)/Ministério do Desenvolvimento Social (Ministry of Social Development). Public notice No.01/2013.

Article based on the thesis by JTC OLIVEIRA, entitled "Avaliação dos Restaurantes Populares no âmbito da Segurança Alimentar e Nutricional". Universidade Federal de Santa Catarina; 2018.

How to cite this article

Oliveira JTC, Gabriel CG, Machado ML, Réos MF, Soar C, DKR Venske. Government-Subsidized Restaurants as promoters of the realization of the Human Right to Adequate Food: Proposal of an evaluation model. Rev Nutr. 2019;32:e180193. http://dx.doi.org/10.1590/1678-9865201932e180193
} 


\section{Methods}

This is an evaluation study. The Evaluation Matrix was elaborated from five stages: systematized revision for elaboration of the theoretical-logical model; immersion process; construction of the preliminary theoretical-logical model; consensus workshops, through the traditional committee technique; elaboration of the evaluation matrix proposal; and external consensus with specialists in the subject and in the implementation and management of Government-Subsidized Restaurants.

\section{Results}

The proposed matrix contemplates two dimensions: Political-Organizational, with the subdimensions: Management, Structure and Target Public; and Technical-Operational, with the sub-dimensions: Adequate Food, Food and Nutrition Education, and Extended Public Assistance. Twenty-four indicators and 29 measures were listed.

\section{Conclusion}

The findings point to the need for advances in evaluation methodologies that contemplate Food and Nutrition Security as the guiding principle of the actions performed by Government-Subsidized Restaurants. Thus, the evaluation matrix presented aims to contribute to the improvement of the GSR as a multifunctional tool, promoter of Food and Nutrition Security and the realization of the Human Right to Adequate Food within the National Food and Nutrition Security Policy.

Keywords: Food and Nutrition Security. Restaurants. Public Policy.

\section{R E S U M O}

\section{Objetivo}

Apresentar um modelo de avaliação para os Restaurantes Populares no âmbito da Política Nacional de Segurança Alimentar e Nutricional.

\section{Métodos}

Trata-se de um estudo de avaliabilidade. A Matriz Avaliativa foi elaborada a partir de cinco etapas: revisão sistematizada para elaboração do modelo teórico-lógico; processo de imersão; construção do modelo teórico-lógico preliminar; oficinas de consenso, por meio da técnica de comitê tradicional; elaboração da proposta da matriz avaliativa; e consenso externo com especialistas na temática e na implantação e gestão de Restaurantes Populares.

\section{Resultados}

A Matriz proposta contempla duas dimensões: Político-Organizacional, com as subdimensões: Administração, Estrutura e Público Frequentador; e Técnico-Operacional, com as subdimensões: Alimentação Adequada, Educação Alimentar e Nutricional e Assistência Ampliada ao Público Frequentador. Foram definidos 24 indicadores e 29 medidas.

\section{Conclusão}

A literatura científica investigada apontou a necessidade de avanços em metodologias avaliativas que contemplem a Segurança Alimentar e Nutricional enquanto norteadora das ações executadas pelos Restaurantes. Assim, a Matriz Avaliativa apresentada visa contribuir para a melhoria dos Restaurantes Populares como ferramenta multifuncional promotora da Segurança Alimentar e Nutricional e da realização do Direito Humano à Alimentação Adequada dentro da Política Nacional de Segurança Alimentar e Nutricional.

Palavras-chave: Segurança Alimentar e Nutricional. Restaurantes. Política Pública.

\section{NTRODUCTIO N}

Government-Subsidized Restaurants (GSR) are the oldest public equipment related to food, nutrition, and the fight against hunger in Brazil, dating from the 1940s. They aim to facilitate access to healthy and adequate food, through the provision of free or low priced meals, prioritizing the population in social vulnerability [1-3]. 
Other countries have government programs aimed at promoting access to food for vulnerable populations, such as Peru (Government-Subsidized Kitchens), Spain (Social Kitchens), Argentina (Community Kitchens) and Canada (Community Food Programs). Still, "soup kitchens", similar to communal kitchens, are found in countries such as Mexico, Peru, Uruguay, the United States of America and Colombia [4].

A comparative study carried out between the Brazilian GSR system and the Spanish soup kitchens showed similarities in their objectives, i.e., the distribution of meals to populations with little access to adequate food, aiming to fight hunger and malnutrition [5]. However, when compared to international experiences, the Brazilian proposal has broader characteristics in the use of this equipment, mainly because it is applied as a Food and Nutrition Security (FNS) action, under the spotlight of the Human Right to Adequate Food (HRAF) [6].

Since 2003, the Government-Subsidized Restaurant Program has been part of the Zero Hunger Program, being governed by the then Ministry of Social Development and Hunger Reduction and, since 2019, it has been allocated to the Special Office for Social Development of the Ministry of Citizenship [1]. Since 2006, GSR have been a part of the Sistema Nacional de Segurança Alimentar e Nutricional (SISAN, National Food and Nutrition Security System), which has been included in the Equipamentos Públicos de Segurança Alimentar e Nutricional (EPSAN, Public Equipment of Food and Nutrition Security), which includes communal kitchens, food banks, supply centers, distribution centers family-based farming, city fairs and public markets. In this context, they aim to guarantee the realization of the HRAF and the promotion of FNS $[7,8]$.

In 2014 there were 204 government-subsidized restaurants in Brazil, with the Southeast region accounting for $50 \%$ of these. In that year, these restaurants served about 209,000 people with meals served on at least five days per week, at an average cost of BRL1.70 per meal [9]. Despite the expansion of GSR, from 99 units in 2009 to 204 in 2014, these restaurants present a history of constant instabilities, often marked by a temporary character with fragmentation of their actions, depending on the political prioritization and management profile.

However, considering the panorama of social inequalities in Brazil, they remain necessary and urgent [7] and, therefore, should be strengthened as a public policy [9]. When well structured and with a committed management, they contribute to local development and to the local economy, going further than a simple compensatory strategy [10]. Also, if well conducted, they represent real alternatives to guarantee the HRAF [11] and to improve levels of Food and Nutrition Insecurity (FNI) $[6,8]$.

From this perspective, concluding that Brazilian GSR are equipment exclusively dedicated to offering low-cost meals [7] is a short-sighted perspective. In addition, they are highly complex equipment that should promote other actions of social development, employment and income generation, and strengthening citizenship principles, characterizing themselves as a multifunctional structure within the Política Nacional de Segurança Alimentar e Nutricional (PNSAN, National Food and Nutrition Security Policy). Thus, their implementation demands compliance with the assumptions of FNS actions and programs, involving economic, social, environmental and cultural aspects [3].

Considering the potential of GSR in promoting the implementation of the HRAF and the lack of evaluative studies with this focus, the objective of this article is to propose an Evaluation Matrix for restaurants in the context of the PNSAN. In this regard, it is worth noting that the quarterly monitoring of government-subsidized restaurants by the Ministry of Citizenship is still carried out in a timely basis, and not in a very thorough manner. Thus, this proposal is also supported by the 
understanding of the evaluation as an activity that must occur in a parallel way to the other actions and inherent to the Program, aiming to qualify the management of these equipment [12].

\section{METHODS}

It is an evaluation study, which is characterized as a preliminary and systematic evaluation process allowing a thorough understanding of the program, and a prior assessment of the various evaluation possibilities. As a result, an evaluation plan which is appropriate to the needs of all stakeholders is sought [12].

One of the essential components of the evaluation plan is the Evaluation Matrix. Its construction considered the academic interest of this evaluation and started from the assumption of the GSR as an equipment of the PNSAN and, therefore, an intervention that assumes the objective of promoting the HRAF. In addition, the Evaluation Matrix was prepared based on the evaluation of the normative type, which has the objective of allowing an evaluation on any interventions relating to their norms and criteria [13]. The Evaluation Matrix was constructed from five stages, based on the components proposed by Trevisan \& Walser [14] (Figure 1).

The first stage consisted of a systematic review and analysis of the current legislation on EPSAN and, specifically on GSR, in a process of conceptual conquest of the reality of the object to be evaluated [15], and with the objective of developing an initial theory regarding the program [14]. This database search was carried out until April 2018, in the Coordenação de Aperfeiçoamento de

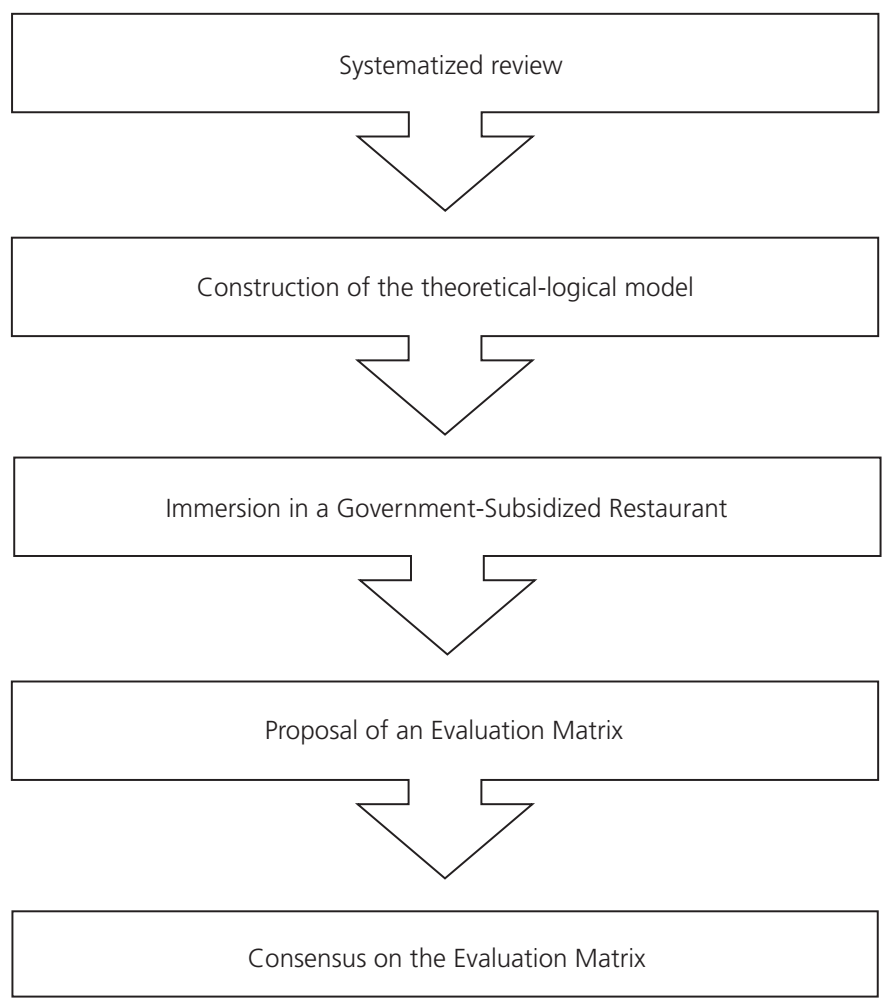

Figure 1. Flowchart of methodological steps. Florianópolis (SC), Brazil (2018). 
Pessoal de Nível Superior (CAPES, Coordination for Higher Education Staff Development), Science Direct, Scientific Electronic Library Online (SciELO), Virtual Health Library (VHL), Scopus, Directory of Open Access Journals, Database of theses and dissertations, Brazilian Digital Library of Theses and Dissertations, and Google Scholar databases. The search strategies used were: [("restaurante popular" OR "cozinha comunitária" OR "banco de alimentos" OR "equipamentos públicos de segurança alimentar e nutricional" OR "comedores populares" OR "comedores sociais" OR "comedores comunitários" OR "government-subsidized restaurant" OR "community restaurants" OR "soup kitchens" OR "community canteens" OR "government-subsidized restaurant program") AND (avalia* OR evalua*)].

Articles, theses and dissertations published in the databases between January 2007 and April 2018 were included in this study, which involved aspects related to the organizational and institutional context of the EPSAN. The criteria for the exclusion of the documents were: duplicated documents; documents without an abstract; documents not fully available; and documents specifically referring to hygienic-sanitary aspects. Paper selection started from reading titles and abstracts. Subsequently, the complete documents were read, with the selection of those of interest. Two researchers were responsible for reading and selecting these articles.

The second stage involved the construction of the proposal of the Theoretical-Logical Model (TLM), as a representation of the Program and its movements and relations, translating the theoretical and practical propositions of the object to be evaluated into a figure. Also considering the importance of the TLM as a tool to guide the Evaluation Matrix, the third step of the methodology involved a one-day immersion process in a GSR located in the state of Santa Catarina (South of Brazil). Among the advantages of immersion, the researchers highlight the possibility of comparing theoretical data with reality, as well as the contemplation of unexpected facts [16]. The choice of this restaurant was for convenience, considering aspects of interest, namely: the recent structural reform of this GSR in 2017, the fact that it presents scales of values for access, and for serving about 600 people per day. From the immersion, it was possible to verify if the TLM had the proper similarity with the object of study.

In the fourth step, a proposal for an Evaluation Matrix was made, containing dimensions, sub-dimensions, and evaluation indicators of GSR with their respective rationales. This proposal was discussed and agreed in three consensus workshops, in a total of 12 hours, through the traditional committee technique [17]. The consensus allows the elaboration of a reference, involving technical aspects of the analyzed question and considering the ethical and political elements [15]. It is essential in order to generate recommendations for the evaluation proposal, increasing its plausibility [14]. Four Ph.D. professors and three postgraduate students with FNS and public policy evaluation expertise, participants of two research groups with experience in health assessment and FNS.

In the last step, the Matrix was evaluated by specialists outside the research group, with experience in the implementation and management of GSR. A representative of the Conselho Nacional de Segurança Alimentar e Nutricional (CONSEA, National Council for Food and Nutrition Security), two representatives of the General Coordination of Public Equipment of the National Food and Nutrition Security Office (an agency under the umbrella of the MDS), two nutritionists who are certified GSR technicians, and a general coordinator with GSR management experience. An e-mail was sent to the specialists with the proposal of an Evaluation Matrix, requesting suggestions for its adequacy.

These suggestions were evaluated by the researchers considering their relevance to the objective of this assessment, the TLM and the rationales. All the specialists received the adjusted 
Evaluation Matrix, with the justifications for the changes made, being questioned if they all agreed with this new proposal. Upon agreement between all specialists, the Matrix was approved.

This research was approved by the Research Ethics Committee of the university, Protocol No.1.160.850.

\section{RE S U L T S}

The systematized review allowed an initial identification of 102 studies. After applying the inclusion and exclusion criteria, 29 studies were selected, of which, twenty articles and nine dissertations. The study objects included public equipment in Brazil (83.0\%), Argentina (6.5\%), Canada (3.5\%), Peru (3.5\%) and the United States of America (3.5\%).

The review evidenced that in the literature, most studies are focused on the profile and user satisfaction, with an important focus on the evaluation of hygienic sanitary aspects and/or the analysis of the nutritional composition of the menus. Although the review was extended to all EPSAN, the majority (86\%) of these studies had Brazilian GSR as their object of study. Also, it is noteworthy that only $17 \%$ of the studies were related to international public equipment and/or programs.

The studies included mainly the analysis of the socioeconomic indicators of the public, anthropometric measurements and eating habits. Also, some authors included psychosocial indicators of satisfaction, related to the nutritional composition of the offered menus, governmental subsidies and the participation of the public in other social programs. Few advances have been found in terms of the evaluation of these equipment as strategies of the PNSAN [11].

\section{Theoretical-logical model}

Figure 2 presents the model based on the systematized review, the historical retrieval of the object studied, the documentary analysis of laws, norms, decrees and standards that govern the PNSAN, especially the Law No.11.346/2006, the Lei Orgânica de Segurança Alimentar e Nutricional (LOSAN, Organic Law of Food and Nutrition Security), and the Decree No.7.272/2010, which establish the intersectoral and expanded concept of FNS, define the HRAF as a guiding principle and establish the SISAN $[18,19]$ in the country. The main implementation and management tool of the PNSAN is the National FNS Plan [18], which reinforces the importance of the expansion and optimization of GSR [20]. The TLM was exposed and adjusted during the consensus workshops, as well as after the immersion process. These stages allowed the construction of a TLM that presents the flow of action between the theoretical proposal and the intervention.

Despite the importance of the recognition of GSR by the PNSAN as a Program to promote the implementation of the HRAF, these have specific norms established by the MDS prior to the Policy itself, including a manual (2004) and an implementation roadmap (2007) $[1,3,18]$. These documents were also used in the construction of the model, since they guide the construction, structure, location, menu, actions of socialization and food and nutritional education, access prices, meal volume, food purchasing processes and meal production, sizing of human resources, as well as strengthening aspects of citizenship principles with the target public.

The last arrow in Figure 2 indicates the objectives to be achieved by the GSR considering the perfect functioning of the TLM, its dimensions and subdimensions. In summary, it represents what is expected of the object of study, that is, that GSR act as a multifunctional structure within the 


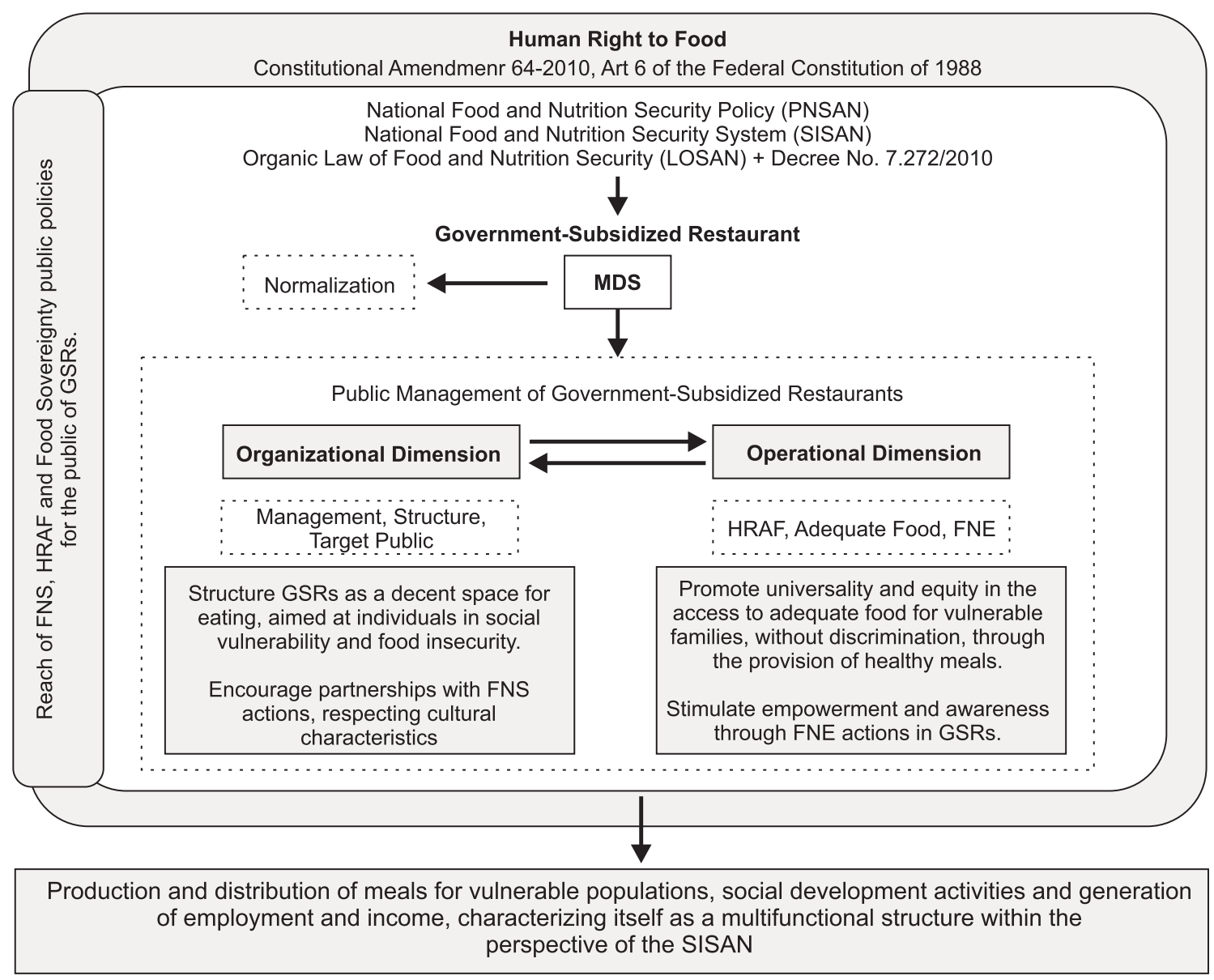

Figure 2. Theoretical-logical model of Government-Subsidized Restaurants. Florianópolis (SC), Brazil (2018).

HRAF: Human Right to Adequate Food; FNE: Food and Nutrition Education; LOSAN: Organic Law of Food and Nutrition Security; MDS: Ministry of Social Development; GSR: Government-Subsidized Restaurant; FNS: Food and Nutrition Security.

perspective of the PNSAN, through the production and distribution of meals, social development and the generation of employment and income [1].

\section{Evaluation Matrix}

The matrix is composed of 2 dimensions, 6 subdimensions, 24 indicators and 29 measures (Chart 1) described in the sequence. Dimensions are the parts of the evaluated object, identifying how it should be structured and which items are critical to the composition of the study object. Other studies have already used these dimensions, such as the management evaluation model of the Programa Nacional de Alimentação Escolar (PNAE, National School Feeding Program), an important program in the area of FNS [21].

Subdimensions are the parts of each dimension. The option of using subdimensions depends on the complexity of the object and the theoretical reference. The indicators express the variables, characteristics or attributes capable of synthesizing or representing the evaluated object. The measures are the measurable versions of the indicator. And, after these items, the parameters and the value judgment for each of the items of the evaluation matrix are defined, composing the final evaluation of the object studied $[22,23]$ 
Chart 1. Evaluation matrix of the actions developed through Government-Subsidized Restaurants in the scope of Food and Nutrition Security. Florianópolis (SC), Brazil (2018).

\begin{tabular}{|c|c|c|}
\hline \multicolumn{3}{|c|}{ Political-Organizational Dimension } \\
\hline Subdimension & Indicator & Measure \\
\hline \multirow{10}{*}{ Management } & \multirow{2}{*}{ 1. Availability } & 1.1. Operating days \\
\hline & & 1.2. Number of people served per day \\
\hline & \multirow{2}{*}{ 2. Human resources } & 1.3. Employees related to the production of meals \\
\hline & & 2.1. Employee training \\
\hline & 3. Financial resources & 3.1. Source of food resources \\
\hline & \multirow{2}{*}{ 4. Pricing } & 4.1. Tiered pricing system \\
\hline & & 4.2. Price of meals \\
\hline & 5. FNS Articulation & 5.1. Existence of articulation with other FNS actions \\
\hline & 6. Waste & 6.1. Waste disposal \\
\hline & 7. Assessment and monitoring & $\begin{array}{l}\text { 7.1. Existence of a local assessment and monitoring } \\
\text { mechanism }\end{array}$ \\
\hline \multirow{4}{*}{ Structure } & 1. Location & 1.1. Location Suitability \\
\hline & \multirow{2}{*}{ 2. Physical structure } & 2.1. Minimum operating structure \\
\hline & & 2.2. Total capacity of the restaurant \\
\hline & 3. Maintenance & 3.1. Maintenance of equipment \\
\hline \multirow[b]{2}{*}{ Target public } & 1. Target public & 1.1. Characterization of the target public \\
\hline & $\begin{array}{l}\text { 2. Prioritization of care for specific } \\
\text { populations }\end{array}$ & $\begin{array}{l}\text { 2.1. Priority assistance for socially vulnerable populations } \\
\text { and FNI }\end{array}$ \\
\hline \multicolumn{3}{|c|}{ Technical-Operational Dimension } \\
\hline Subdimension & Indicator & Measure \\
\hline \multirow{7}{*}{ Adequate food } & 1. Nutritional planning of menus & 1.1. Nutritional adequacy of the menu \\
\hline & 2. Food security & 2.1. Application of safe food production processes \\
\hline & $\begin{array}{l}\text { 3. Supply of food and/or regional } \\
\text { preparations }\end{array}$ & 3.1. Inclusion of food and regional preparations \\
\hline & \multirow[t]{2}{*}{$\begin{array}{l}\text { 4. Prioritization of food produced } \\
\text { through family-based agriculture }\end{array}$} & $\begin{array}{l}\text { 4.1. Acquisition of foods originating from family-based } \\
\text { agriculture }\end{array}$ \\
\hline & & 4.2. Agriculture and food supply partnerships \\
\hline & $\begin{array}{l}\text { 5. Volume of meals produced for the } \\
\text { public }\end{array}$ & $\begin{array}{l}\text { 5.1. Adequacy of food production in relation to the } \\
\text { demand }\end{array}$ \\
\hline & $\begin{array}{l}\text { 6. Public satisfaction with the food } \\
\text { offered }\end{array}$ & 6.1. Conducting customer satisfaction surveys \\
\hline Food and Nutrition Education & 1. FNE related to FNS & 1.1. FNE actions for the public \\
\hline \multirow{5}{*}{ Extended Public Assistance } & $\begin{array}{l}\text { 1. Promotion of other social assistance } \\
\text { actions }\end{array}$ & $\begin{array}{l}\text { 1.1. Application of incentive actions about the participation } \\
\text { of the public in other social welfare actions }\end{array}$ \\
\hline & $\begin{array}{l}\text { 2. FNS situation after the } \\
\text { implementation of the GSR }\end{array}$ & $\begin{array}{l}\text { 2.1. Investigation of FNS conditions after the implementation } \\
\text { of the GSR }\end{array}$ \\
\hline & 3. Socialization activities & 3.1. Promotion of socialization activities \\
\hline & 4. Intersectoral actions & 4.1. Existence of intersectoral actions \\
\hline & 5. GSR visibility & 5.1. External disclosure of GSR actions \\
\hline
\end{tabular}

Note: FNE: Food and Nutrition Education; FNI: Food and Nutrition Insecurity; FNS: Food and Nutrition Security; GSR: Government-Subsidized Restaurant. 


\section{Dimension 1: Political-organizational}

The management of GSR is the responsibility of public administration, which may, among its management options, outsource it. However, this equipment continues to have a public character and is in compliance with governmental regulations [1,3]. It must take place in partnership with several municipal departments, guaranteeing the supply of nutritionally balanced meals, originated from safe food production processes, in a comfortable and easily accessible place, at affordable prices and, preferably, to the socially vulnerable public $[1,3]$.

The political-organizational dimension presents the administrative and functional parameters in which the manager must act. It is arranged in three subdimensions.

The "Management" subdimension consists of activities of related to the planning, organization, direction, and control using human, material, and technical resources $[1,3]$. It is composed of seven indicators. The "Availability" indicator refers to the process of producing meals, and the working hours of the operation [3]. "Human Resources" aims at the dimensioning of personnel for the work of producing and distributing meals $[1,24]$. "Financial Resources" assess the sustainability of GSRs in the medium and long term [1]. The "Pricing" indicator refers to the price of meals being sold [1]. "FNS Articulation" indicates the level of articulation of the restaurant with other actions of FNS [1]. The "Waste" indicator evaluates the incentives to biological treatment actions of organic residues [1]. The "Assessment and monitoring" indicator refers to GSR services, even in cases of an outsourced administration. It also includes the social control of public administration [1].

The "Structure" sub-dimension evaluates whether GSR are strategically located. It also includes the basic infrastructure for the operation, and the possibility of restaurants to work as multipurpose spaces [1]. It has three indicators. The "Location" indicator refers to the location of the GSR, prioritizing regions with high numbers of formal and/or informal low-income workers, and also in peripheral areas where there is a higher concentration of population in conditions of risk or food and nutrition vulnerability [3]. "Physical structure" refers to the process of adapting the GSR to the standards for establishments producing meals and the basic urban infrastructure: public water supply and electricity supply networks, sewage and rainwater collection, and the physical access to the GSR $[1,3]$. The "Maintenance" indicator refers to the scheduled and periodic maintenance of the restaurant equipment [1].

The "Target public" sub-dimension refers to the public served by the GSR, which should prioritize populations in situations of social vulnerability $[1,3]$. It has two indicators. The "Target public" indicator refers to the characterization of the potential public, their socioeconomic profile, dietary habits, level of income, occupation, among others [1]. "Prioritization of care for specific populations" is understood as the actions developed to guarantee adequate care to the recipients of the Social Assistance Policy [1,25].

\section{Dimension 2: Technical-Operational}

The technical-operational dimension aims to demonstrate the commitment of the GSR management to provide an adequate and affordable meal and also to enable a multifunctional space to strengthen citizenship principles, being arranged in three sub-dimensions. 
The sub-dimension "Adequate Food" analyzes the food and nutritional quality of meals. These must be nutritionally balanced, originated from safe food production processes, predominantly with regional products, at affordable prices, served in appropriate and comfortable places, in order to guarantee the dignity of eating. This subdimension includes six indicators. The indicator "Nutritional adequacy of the menus" refers to the nutritional adequacy of meals and the need to have a nutritionist responsible for them $[1,24]$. "Food Security" evaluates the production of food through the use of safe processes, according to the adequate food handling practices $[1,26]$. The indicator "Supply of food and/or regional preparations" refers to the supply of foods that stimulate the biodiversity of species, the recognition of the cultural heritage and historical value of food, as well as foods that promote the region's typical cuisine [1]. "Prioritization of food produced through family-based agriculture" evaluates the process of buying and using food from local and/or regional family-based farming. The indicator "Volume of meals produced for the public" refers to the volume and its adequacy to the number of diners attending the GSR [1]. The indicator "Public satisfaction with the food offered" analyzes the adequacy of the menu to the preference of the public being served, observing the local eating habits [1].

The Subdimension "Food and Nutrition Education" (FNE) refers to the need of the GSR to promote a continuous and permanent, transdisciplinary, intersectoral and multiprofessional practice that aims to promote healthy eating habits in an autonomous and voluntary way [27]. This sub-dimension is composed by the "FNE related to FNS" indicator, which refers to the promotion of FNE actions, to the preservation and recovery of food culture, to combating waste, and to the promotion of health. It also includes activities aimed at stimulating society to fight hunger and to adopt healthy eating habits [1].

The sub-dimension "Extended Public Assistance" rescues adequate eating habits as a fundamental right of the human being, inherent to the dignity of the individual and indispensable for the realization of constitutional rights, and the public authority must adopt the policies and actions that are necessary to promote and guarantee FNS for the population [18]. This subdimension involves four indicators. "Promoting other social welfare actions" is an indicator which refers to the partnerships that can be established with GSR, with emphasis on the Social Welfare Office, through guidance on social programs developed by the city in which the GSR is located [1]. The "FNS Situation after the implementation of the GSR" indicator evaluates the capacity of actions of social development and generation of employment and income [3]. "Socialization activities" is the indicator which addresses the functionality of the GSR as a multipurpose space for various activities, contributing to the strengthening of socialization and citizenship principles [1]. The "Intersectoral Actions" indicator evaluates partnerships that can be established at different layers of the government and with other entities, such as with municipal departments, councils, universities, among others [1]. The "GSR Visibility" indicator evaluates the disclosure of GSR actions, aimed at a greater adherence of the society to the processes $[1,3]$.

\section{DISCUSSION}

Despite the constant evolution of the FNS concept, the review showed that most studies are still focused on the nutritional evaluation of the menus and/or the hygienic-sanitary regulations 
of the place of food production. Food and Nutrition Security covers several dimensions belonging to different socio-organizational levels, so that it exceeds the capacity to measure only one or two indicators [28]. The recognition of the different meanings of FNI will allow the objectives to be broadened so that the focus is no longer on food, but individuals and human dignity, with the goal that FNS policies are directed and integrated into the inalienable right to adequate food [29].

The proposed theoretical-logical model aims to place GSR as EPSAN, linked to the PNSAN and promoters of the HRAF. In this scenario, modeling is an important step for the questioning to be adequate and accurate, aiming for more precise contributions. In this way, the evaluation process can contribute more effectively to decision-making [30]. In the model, the GSR function was interpreted from the perspective of two dimensions: Political-Organizational and Technical-Operational.

The Evaluation Matrix synthesizes the theory of the evaluated object, based on the existing literature and the current legislation. For greater consistency and relevance, the proposal was discussed in consensus workshops with specialists. The realization of the consensus workshops and the submission of the Matrix to external specialists was important, especially in the face of a scenario of scarce publications about the evaluation of GSR, within the scope of interest. According to literature, the choice of participants for consensus is a successful and productive device that allows the shared development of an evaluation tool, as well as the protagonism and clarification of these representatives on the context of the object of study of which they are part [17].

In this process, it is up to the researcher to incorporate or not the suggestions and the compilation of contributions. This method is very important for the validation of instruments [31]. Considering the detail and depth of each stage, the originality and relevance of the constructed Evaluation Matrix is highlighted, which provides a broad evaluation of the object of study.

With regard to evaluation, it should be able to ascertain to whom and in what way the interventions are planned and intended, as well as the results and impacts generated [32]. Specifically within FNS, the evaluation is admittedly a complex and challenging action, since it involves determinants, needs and interests that fall into different spheres of society [30]. Considering this complexity (intersectoral, participatory and interdisciplinary), it is necessary, in addition to discussing the limits of traditional methods of assessment, to advance the construction of integrative theoretical and methodological approaches [21,32,33].

In view of this scenario, it is accepted that, as important as the existence of the equipment, is the existence of constant monitoring mechanisms that subsidize the evaluation of the results, the optimization of the performance of these mechanisms, the existing political and administrative challenges and the impact of the policies in the FNS of the population [28,34]. A research on community kitchens performed in Mexico in 2011 identified the need for continuous evaluations to improve customer care, verify compliance with objectives, and analyze the health effects of the food in the public. The lack of methodological tools to estimate the contribution of this program to improving the food situation of the beneficiary population was also observed as a limiting factor in the Mexican program [35].

Thus, the need for studies that contemplate FNS as a compass to guide the actions performed by the EPSAN is highlighted. In addition, the evaluation of GSR must be understood as a strategy inherent to the program itself, fundamental for measuring the benefits of the program and ensuring that it achieves its objectives, in more effective and efficient ways [12]. Improvement measures for GSR lead to their optimization as tools for coping with hunger, contributing to better FNS scores and the guarantee to the $\operatorname{HRAF}[7,36]$. 
It should be noted that, when incorporated into the PNSAN [19], the GSR have their objectives broadened while also responding to the concept of FNS. In this line, the intersectoriality, a central element of the PNSAN, must also be analyzed as an element of the GSR itself. The intersectoriality in FNS is consecrated as a strong strategy to contemplate actions related to the production, commercialization, supply, access and consumption of food [37]. Government-subsidized restaurants incorporate all these actions on a daily basis, from the acquisition of food produced in family-based farming systems to the correct use of their organic waste.

The intersectoriality of Community Food Programs, developed in Canada through the integration of food banks, soup kitchens and social welfare centers stands out for recognizing that the $\mathrm{FNI}$ encompasses broader sociocultural challenges. Therefore, the approach to these programs should extrapolate food supply and include other intersectoral actions that assist in the social, cultural, financial, and health equity of the population served [38].

In addition to a healthy and adequate diet, GSR should guarantee dignity to the act of feeding, strengthening citizenship principles of the most vulnerable groups, also from the involvement of different sectors of government and society. In this context, the role of GSR as agents of a critical FNE and as constructors of citizens who are aware of their rights is highlighted. This expanded function of GSR in Brazil differs from the assumptions of the Peruvian Popular Kitchens, where the performance of these equipment is focused solely on improving the nutritional status of the most vulnerable groups, functioning as a low-cost food supply network [39].

Considering these reflections, it is important to highlight that the construction of active citizenship principles, in which the population understands the HRAF, depend on FNE actions that stimulate an affective learning process, considering the social representations and socioeconomic conditions of those involved [11]. This is because food practices do not only refer to the human need to eat, but they mainly permeate cultural, social, family traditions, values, beliefs, time, and preferred forms of food preparation [7]. It should also be pointed out that FNE actions in the equipment have the potential to reach different kinds of audiences, allowing the expansion and foundation of the rights, as well as the promotion of healthy food practices, through a collective and participative work with the community [40].

The GSR program should be an educational one - stimulating the defense of human rights, and emancipatory -, aiming at the autonomy of the subjects [41]. The existence of policies and programs for direct access to food should follow premises that are essential to a good performance, such as: focus, strong references to human rights, good communication with other social policies that beneficiaries participate in, and the promotion of healthy habits.

In the international context, it is noted that most countries that have achieved important goals regarding reducing hunger have stable and strong social protection policies targeting vulnerable population groups. In these countries, the commitment to fight FNI has achieved satisfying results despite problems such as population growth, market volatility and rising food and energy prices, rising unemployment rates, and the economic recessions of the late 1990s and 2008 [42].

Preliminary results from a soup kitchen study in the United States have shown that the food and nutritional needs of populations in social vulnerability have long been perceived as a public health problem. The results also suggested that improving the quality of meals, of FNE and of food policies as a whole, helps to give people in social vulnerability the dignity of the opportunity to restore their health and quality of life. The researchers said that improving access to adequate food is beneficial and viable [43]. 
Despite the relevance of strategies to fight hunger and misery as proposed by the GSR program, the records of periods when several units throughout the country had to be closed are something to be worried about, and the instability sometimes experienced by the equipment, which recently had its information and guidelines taken from government websites. Still, one can wonder about what could be the cause for a certain 'invisibility' of the theme in the available literature [6].

The strengthening of the existence and continuity of GSR as a right should be emphasized, since it is a tool that allows vulnerable populations the access to food, and contributes to the guarantee of the HRAF and FNS. It is important to emphasize the need to broaden the understanding of this program beyond a welfare practice, but as a promoter of social emancipation through the exercise of a human right and strengthening social control [11].

\section{CONCLUSION}

Based on the above, evaluative studies that contemplate EPSAN, especially GSR, are still necessary, as an integral part of the PNSAN. It is understood that evaluations with this design are important to give visibility to these equipment and to strengthen them as elements that promote the accomplishment of the HRAF and the qualification of the Brazilian indexes of FNS. It is also pointed out that the evaluative process of social programs such as the GSR should be an integrative approach, since its isolated use disqualifies the intersectoral and multifunctional nature of the same.

In this sense, it is important to highlight the relevance of this study, since it presents an Evaluation Matrix that contributes to the appreciation of GSR as a multifunctional tool within the PNSAN, increasing its potential beyond the provision of nutritionally adequate meals. This Evaluation Matrix, by locating limits and potentialities in the implementation of GSR, contributes to the optimization of their actions, expanding the scope and the impact of their actions. Another contribution to be highlighted is the potential for national and international dissemination of the expanded implementation of GSR and their potential, considering its scope and the decades of its existence.

It is hoped that the proposed Evaluation Matrix can be qualified and applied in different contexts, contributing to minimizing regional disparities in the number of GSR and stimulating scientific production in this field.

Among the limiting factors of this study is the absence of the definition of "value judgment" for the components of the Evaluation Matrix. However, it is believed that this model can be adapted to each reality, according to the specificity of each country and its population. Likewise, it is also accepted that the proposed model did not elaborate on aspects such as the financing issues or the impact of GSR on the public. However, it is reinforced that the proposal focused on the construction of an Evaluation Matrix for the characterization of the actions that should be prioritized by the managers of the GSR, seeking to obtain an outlook that could support future deepening into the subject.

\section{CONTRIBUTORS}

JTC OLIVEIRA and CG GABRIEL were responsible for the conception, design, analysis, interpretation of data and writing the article. ML MACHADO, MF RÉOS, C SOAR, DKR VENSKE were responsible for the conception, design, review and final approval of the article. 


\section{REFERENCES}

1. Ministério do Desenvolvimento Social e Combate à Fome (Brasil). Manual Programa Restaurante Popular. Brasília: MDS; 2004 [citado 2017 jan 25]. Disponível em: http://bvsms.saude.gov.br/bvs/publicacoes/projeto_ logico_restaurante_popular

2. Costa D. Experiência brasileira em Restaurantes Populares. Bol Oficina Sanit Panam. 1947;26:415-21.

3. Ministério do DesenvolvimentoSocialeCombateà Fome(Brasil). Restaurantes Populares: roteiro de implantação. Brasília: MDS; 2007 [citado 2017 fev 26]. Disponível em: http://www.ufff.br/renato_nunes/files/2011/04/ Roteiro-de-Implanta\%C3\%A7\%C3\%A3o-Restaurantes-Populares-visualiza\%C3\%A7\%C3\%A3o.pdf

4. Souza LR, Belik W. O planejamento da política de alimentação: uma análise a partir dos casos do México, Brasil e Peru. Segur Alim Nutr. 2012;19(2):111-29. http://dx.doi.org/10.20396/san.v19i2.8634615

5. Kraemer FB, Gracia-Arnaiz M, Prado SD, Carvalho MCVS. A comida para o alívio do sofrimento social: restaurantes populares no Brasil e comedores sociales na Espanha. In: Prado SD, Kraemer FB, Seixas CM, Freitas RF, editores. Curitiba: Série Sabor Metrópole; 2015.

6. Padrão SM, Aguiar OB. Restaurante popular: a política social em questão. Physis. 2018;28(3):e280319. http://dx.doi.org/10.1590/S0103-73312018280319

7. Godoy KC, Sávio KEO, Akutsu RC, Gubert MB, Botelho RBA. Perfil e situação de insegurança alimentar dos usuários dos Restaurantes Populares no Brasil. Cad Saúde Pública. 2014;30(6):1239-49. http://dx.doi. org/10.1590/0102-311X00084013

8. Governo do Distrito Federal (Brasil). Decreto $n^{\circ} 33.329$, de 10 de novembro de 2011. Regulamenta a Lei n4.601, de 14 de julho de 2011, que institui o Plano pela Superação da Extrema Pobreza: DF sem Miséria, e dá outras providências. Diário Oficial do Distrito Federal; 2011 [citado 2018 out 26]. Disponível em: http:// www.sinj.df.gov.br/sinj/Norma/69851/exec_dec_33329_2011.html

9. Ministério do Desenvolvimento Social e Combate à Fome (Brasil). Mapeamento da Segurança Alimentar e Nutricional. Brasília: MDS; 2015 [citado 2017 jan 30]. Disponível em: https://aplicacoes.mds.gov.br/sagirmps/ ferramentas/docs/MapaSAN_final.pdf

10. Zanini E, Schneider MB. Restaurantes populares em Toledo: um programa de desenvolvimento. Econ Desenvol. 2016;27(2):243-56. http://dx.doi.org/10.5902/1414650920984

11. Araújo FR, Araújo MAD, Maia PB, Medeiros GCBS, Souza FJV. Programa Restaurante Popular: uma alternativa para promover o direito humano à alimentação adequada? Emancipação. 2015;15(1):142-54. http://dx.doi. org/10.5212/Emancipacao.v.15i1.0009

12. Thurston W, Potvin L. Evaluability assessment: A tool for incorporating evaluation in social change programmes. Evaluation. 2003;9(4):453-69. http://dx.doi.org/10.1177/1356389003094006

13. Contandriopoulos AP, Champagne F, Denis JL, Pineault R. A avaliação na área da saúde: conceitos e métodos. In: Fiocruz E, editor. Avaliação em saúde: dos modelos conceituais a práticas da implantação de programas. Rio de Janeiro: Hartz; 1997. p.29-47.

14. Trevisan MS, Walser TM. Evaluability assessment: Improving evaluation quality and use. New Delhi: Sage Publications; 2014.

15. Hartz ZMA, Silva LMV. Avaliação em saúde: dos modelos teóricos à prática na avaliação de programas e sistemas de saúde. Rio de Janeiro: Fiocruz; 2005.

16. Cooper DR, Schindler PS. Métodos de pesquisa em administração. 12a ed. Porto Alegre: McGraw Hill Brasil; 2016.

17. Uchoa AC, Gondim GMM, Barreto MA, Rocha NSPD, Rocha PDM. Utilizando técnicas de consenso: potencialidades e limites na avaliação de informações em saúde. In: Meta-avaliação da atenção básica à saúde: teoria e prática. Rio de Janeiro: Fiocruz; 2008. p.253-82.

18. Presidência da República (Brasil). Decreto n7.272, de 25 de agosto de 2010. Regulamenta a Lei n¹1.346, de 15 de setembro de 2006, que cria o Sistema Nacional de Segurança Alimentar e Nutricional - SISAN com vistas a assegurar o direito humano à alimentação adequada, institui a Política Nacional de Segurança Alimentar e Nutricional - PNSAN, estabelece os parâmetros para a elaboração do Plano Nacional de Segurança Alimentar e Nutricional, e dá outras providências. Diário Oficial da União. 2010 [citado 2019 maio 15]. Disponível em: http://www.planalto.gov.br/ccivil_03/_ato2007-2010/2010/decreto/d7272.htm

19. Presidência da República (Brasil). Lei n¹1.346, de 15 de setembro de 2006. Cria o Sistema Nacional de Segurança Alimentar e Nutricional - SISAN com vistas em assegurar o direito humano à alimentação 
adequada e dá outras providências. Diário Oficial da União. 2006 [citado 2017 jan 26]. Disponível em: http:// www.planalto.gov.br/ccivil_03/_ato2004-2006/2006/lei/111346

20. Câmara Interministerial de Segurança Alimentar e Nutricional (Brasil). Plano Nacional de Segurança Alimentar e Nutricional - PLANSAN 2016-2019. Brasília: CAISAN; 2017 [citado 2018 fev 26]. Disponível em: http:// www.cfn.org.br/wp-content/uploads/2016/05/PLANSAN-2016.pdf

21. Gabriel CG, Calvo MCM, Ostermann RM, Vasconcelos FAG. Proposta e aplicabilidade de modelo para avaliação da gestão municipal do Programa Nacional de Alimentação Escolar. Cad Saúde Pública. 2014;30(8):1731-44. http://dx.doi.org/10.1590/0102-311X00033913

22. Calvo MCM, Henrique F. Avaliação: algumas concepções teóricas sobre o tema. In: A odontologia e a estratégia saúde da família. Tubarão: Unisul; 2006. p.115-39.

23. Tanaka O, Melo C. Avaliação de programas de saúde do adolescente, um modo de fazer. São Paulo: Universidade de São Paulo; 2001.

24. Conselho Federal de Nutricionistas (Brasil). Resolução CFN N600, de 25 de fevereiro de 2018. Dispõe sobre a definição das áreas de atuação do nutricionista e suas atribuições, indica parâmetros numéricos mínimos de referência, por área de atuação, para a efetividade dos serviços prestados à sociedade e dá outras providências. Brasília: CNF; 2018 [citado 2019 maio 13]. Disponível em: http://www.cfn.org.br/wp-content/ uploads/resolucoes/Res_600_2018.htm

25. Conselho Nacional de Segurança Alimentar e Nutricional (Brasil). Subsídios para a construção da Política Nacional de Segurança Alimentar e Nutricional. 2009 [citado 2017 out 28]. Disponível em: http://www4. planalto.gov.br/consea/eventos/plenarias/documentos/2009/subsidios-para-a-construcao-da-politicanacional-de-seguranca-alimentar-e-nutricional-10.2009

26. Agência Nacional de Vigilância Sanitária (Brasil). Resolução RDC n²16. Dispõe sobre Regulamento Técnico de Boas Práticas para Serviços de Alimentação. Brasília: ANVISA; 2004 [citado 2017 março 26]. Disponível em: http://portal.anvisa.gov.br/documents/33916/388704/RESOLU\%25C3\%2587\%25C3\%2583O-RDC \%2B N\%2B216\%2BDE\%2B15\%2BDE\%2BSETEMBRO\%2BDE\%2B2004.pdf/23701496-925d-4d4d-99aa-9d47 $9 \mathrm{~b} 316 \mathrm{c} 4 \mathrm{~b}$

27. Ministério do Desenvolvimento Social e Combate à Fome (Brasil). Marco de referência de educação alimentar e nutricional para as políticas públicas. Brasília: MDS; 2012 [citado 2017 nov 28]. Disponível em: http://www. cfn.org.br/wp-content/uploads/2017/03/marco_EAN.pdf

28. Kepple AW, Gubert MB, Segall-Corrêa AM. Metodologias de avaliação de segurança alimentar e nutricional. In: Silva CO, Sousa DA, Pascoal GB, Soares LP, editores. Segurança Alimentar e Nutricional. Rio de Janeiro: Editora Rubio; 2016.

29. Albuquerque MFM. A segurança alimentar e nutricional e o uso da abordagem de direitos humanos no desenho das políticas públicas para combater a fome e a pobreza. Rev Nutr. 2009;22(6):895-903. http://dx. doi.org/10.1590/S1415-52732009000600011

30. Brousselle A, Champagne F, Contandriopoulos AP, Hartz Z. Avaliação: conceitos e métodos. Rio de Janeiro: Fiocruz; 2011.

31. Minayo MCS. Construção de indicadores qualitativos para avaliação de mudanças. Rev Bras Educ Med. 2009 [citado 2019 maio 15];33(1 Supl1):83-91. Disponível em: http://www.scielo.br/pdf/rbem/v33s1/a09v33s1.pdf

32. Carvalho AT, Almeida ER, Nilson EF, Ubarana JA, Fernández IM, Immink M. Métodos de análise em programas de segurança alimentar e nutricional: uma experiência no Brasil. Ciênc Saúde Coletiva. 2013;18(2):309-21. http://dx.doi.org/10.1590/\$1413-81232013000200003

33. Magalhães R. Avaliação de políticas e iniciativas públicas de segurança alimentar e nutricional: dilemas e perspectivas metodológicas. Ciênc Saúde Coletiva. 2014;19(5):1339-46. http://dx.doi.org/10.1590/1413-8 1232014195.12202013

34. Anjos LA, Burlandy L. Construção do conhecimento e formulação de políticas públicas no Brasil na área de segurança alimentar. Ciênc Saúde Coletiva. 2010;15(1):19-23. http://dx.doi.org/10.1590/S1413-81232 010000100003

35. Balam-Gómez M, Uicab-Pool G, Uch-Puc P, Sabido-Barrera J. Evaluación de los comedores comunitarios en Tizimín, Yucatán, México: percepciones y propuestas del personal y beneficiarios. Enferm Univ. 2013 [citado 2019 maio 15];10(4):125-32. Disponível em: http://www.scielo.org.mx/scielo.php?pid=S1665-70 $632013000400004 \&$ script=sci_abstract\&tlng=en 
36. Garajau NI, Afonso MLM. Articulação intersetorial como estratégia de gestão na Política de Segurança Alimentar e Nutricional no Brasil: análise do Programa Cozinha Comunitária. Segur Alim Nutr. 2016;23:1065-79. http://dx.doi.org/10.20396/san.v23i0.8635603

37. Burlandy L. A construção da política de segurança alimentar e nutricional no Brasil: estratégias e desafios para a promoção da intersetorialidade no âmbito federal de governo. Ciênc Saúde Coletiva. 2009;14(3):851-60. http://dx.doi.org/10.1590/S1413-81232009000300020

38. Ford J, Lardeau MP, Vanderbilt W. The characteristics and experience of community food program users in arctic Canada: A case study from lqaluit, Nunavut. BMC Public Health. 2012;12(1):464. http://dx.doi. org/10.1186/1471-2458-12-464

39. Alcázar, L. ¿Por qué no funcionan los programas alimentarios y nutricionales en el Perú?: riesgos y oportunidades para su reforma. In: Teillier C, editor. Investigación, políticas y desarrollo en el Perú. Lima: Grade; 2007 [citado 2018 out 25]. Disponible en: http://repositorio.grade.org.pe/handle/GRADE/177

40. Soares LP, Santos LMP. Políticas e programas de segurança alimentar e nutricional no Brasil. In: Silva CO, Souza DB, Pascoal GB, Soares LP, editors. Segurança Alimentar e Nutricional. Rio de Janeiro: Rubio; 2016. p.13-23.

41. Yasbek MC. O programa Fome Zero no contexto das políticas sociais brasileiras. São Paulo Persp. 2004;18(2):104-12. http://dx.doi.org/10.1590/S0102-88392004000200011

42. Organización de las Naciones Unidas para la Alimentación y la Agricultura. El estado de la inseguridad alimentaria en el mundo: Cumplimiento de los objetivos internacionales para 2015 en relación con el hambre: balance de los desiguales progresos. Roma: FAO; 2015 [citado 2019 maio 15]. Disponible en: http://www. fao.org/3/a-i4646s.pdfhttp://www.fao.org/3/a-i4646s.pdfmarço

43. Koh KA, Bharel M, Henderson DC. Nutrition for homeless populations: Shelters and soup kitchens as opportunities for intervention. Public Health Nutr. 2016;19(7):1312-4. http://dx.doi.org/10.1017/S136898 0015002682 